This paper investigates the current state and prospects of the development of the European IT services market. A detailed analysis of the economic indicators of the IT market in European countries has been conducted. Marketing characteristics of the external market of IT services were considered, in whose formation a leading role belongs to export deliveries. It has been determined that the capacity of the international segment of the IT services market in most European countries increases by an average of $20 \%$ annually, and the share of IT technologies exports in the overall export structure exceeds $8 \%$. The forecast of changes in the internal market of IT technologies in the post-Soviet countries was analyzed. Based on the results, it was concluded that in the future the capacity of the domestic IT services market could increase and, in 2024, in particular in Ukraine, would exceed the volume of USD 2 billion. The results of studying the level of prices for IT services in the post-Soviet countries suggest that they mainly correspond to the prices for similar services in different groups of European countries (with different material capabilities). That means that for IT service consumers in countries with a low standard of living, price characteristics are not an obstacle to obtaining the highest quality services from domestic or foreign suppliers. The role and importance of personnel support of the information industry, which is key in the formation and development of the IT services market, have been determined. It has been proven that specialists who attained IT education mostly work according to the skills and competencies obtained, which distinguishes them favorably from specialists in other fields. Despite the tendencies of a certain outflow of specialists outside the countries with a low living level, the number of IT specialists is growing progressively in their economies. In many ways, these trends are facilitated by an increase in the number of graduates from specialized educational institutions

Keywords: marketing research, IT services market, development indicators, market capacity, economic characteristics
UDC 659

DOI: $10.15587 / 1729-4061.2021 .245251$

\section{THE FORMATION OF ECONOMIC AND MARKETING PROSPECTS FOR THE DEVELOPMENT OF THE MARKET OF INFORMATION SERVICES}

Petro Pererva

Corresponding author

Doctor of Economic Sciences, Professor, Head of Department*

E-mail: pgpererva@gmail.com

Stanislav Nazarenko

Postgraduate Student*

Ruslana Maistro

$\mathrm{PhD}$, Associate Professor

Department of Economics and Marketing**

Taras Danko

$\mathrm{PhD}$, Associate Professor

Department of International Business and Finance **

Maya Doronina

Doctor of Economic Sciences, Professor, Senior Researcher

Department of Industrial Policy and Energy Security

Research Center for Industrial Problems of Development of the

National Academy of Sciences of Ukraine

Inzhenernyi lane, 1-a, Kharkiv, Ukraine, 61000

Li ud m y a Sokolova

Doctor of Economic Sciences, Professor

Department of Economic Cybernetics and

Management of Economic Security

Kharkiv National University of Radio Electronics

Nauky ave., 14, Kharkiv, Ukraine, 61166

* Department of Innovative Entrepreneurship Management and International Economic Relations**

** National Technical University «Kharkiv Polytechnic Institute»

Kyrpychova str., 2, Kharkiv, Ukraine, 61002
Received date 05.10.2021 Accepted date 22.11.2021 Published date 28.12.2021
How to Cite: Pererva, P., Nazarenko, S., Maistro, R., Danko, T., Doronina, M., Sokolova, L. (2021). The formation of economic and marketing prospects for the development of the market of information services. Eastern-European Journal of Enterprise Technologies, 6 (13 (114)), 6-16. doi: https://doi.org/10.15587/1729-4061.2021.245251

\section{Introduction}

The volume of the global IT services market was estimated at about USD 600 billion in 2020 and was expected to grow at an average annual growth rate (CAGR) of $7.7 \%$ between 2020 and 2027 [1]. In the future, it is expected that in the field of information technology there will be a significant demand for IT operations, which would actually allow enterprises and organi- zations to focus on their main tasks and reduce operating costs. Increasing attention to the development and widespread use of information technologies and their focus on the consumer in various sectors of the economy increases the demand for the outsourcing of services in the field of information technology. This factor is decisive in the development of an information market that is constantly evolving and growing [2]. There are also growing needs for the ability to formulate and optimize IT strategies, 
to carry out professional consultations on information support of industrial and commercial activities of industrial enterprises.

Digital technologies have become an important driver of the economic growth, national security, and international competitiveness of each country. The digital economy significantly affects the trajectory of the world and the social well-being of ordinary citizens, the efficiency of production and commercial activities of enterprises - from the allocation of resources to the distribution of income and growth. In today's competitive and dynamic business environment, few solutions are as important for the success of an organization as choosing a reliable information partner. Most entrepreneurs in certain periods of their activities consider the possibility of using IT outsourcing in their production and commercial operations. This approach makes it possible to create a new impetus for development through access to a skilled outsourcer workforce. In addition, there are actual opportunities to reduce costs for information support of their activities and use new growth opportunities.

Post-Soviet countries are active participants in one of the leading and fastest-growing areas in Europe in the field of global software development services [3,4]. According to the CEE 2019 report, the country's software development sector grew by $19 \%$ in 2018 and is steadily progressing from year to year. In the national economies of European countries, a wide range of information achievements and advantages is offered - from a large personnel reserve of IT specialists and experience in the field of economic efficiency and highly professional technical education [5]. It should also be noted that active participation in the world and European markets of information technologies allows the country to gain certain competitive advantages for the IT industry. In particular, this area of activity belongs to the few sectors of the national economy, which, under the conditions of a difficult political and economic state in the country, is developing quite successfully [6]. At the same time, the potential of the information technology market in many countries of the world has not yet been fully realized [7]. All this predetermines the absolute importance and relevance of scientific research into the economic and marketing characteristics of the national information technology market in order to define its role and place in the European community.

\section{Literature review and problem statement}

Research in the field of information and computer technology market involves various kinds of organizations and associations, scientists, enterprises, and institutions. The reported studies examine the scientific-methodical and practical provisions on understanding the content and essence of the concept of "IT market". The varieties of this market, the use of its proposals in the process of forming competitive advantages of enterprises and organizations, disadvantages and advantages in the introduction and use are considered in detail.

For example, the International Association of Outsourcing Professionals (IAOP) publishes the Global Outsourcing 100 annually, which includes the best IT service providers in the IT market [8]. The rating is based on applications received and evaluated by an independent panel of experts from the IAOP. The main criteria that are the basis for inclusion in the rating are the best projects and their profitability, as well as the innovativeness of the scheme for providing IT services to consumers. However, the results of IAOP research reproduce, firstly, only the best IT projects, and, secondly, do not inform about the details of the presentation of these IT projects to the market, the conditions for their acquisition and use. More accurate results could be obtained when the results of other national and European ratings were taken into consideration, which would give the IAOP proposals greater justification.

In [9], the peculiarities of the formation of the national IT outsourcing market in the country are investigated. However, although IT outsourcing is one of the extremely important components of the market, it is only part of the information and computer technology market. As a result, the research does not give a complete picture of this market and needs its development and advancement. The authors of [10] investigate the existing classifications of components of the information market. They propose to put the original approach to the definition of the term "information services" at the basis of their proposals. At the same time, this term is considered as an economic phenomenon, which is proposed to form the basis of the mechanism of relations between IT service consumer enterprises and their market environment. However, the current development of information technologies no longer puts them into a series of phenomenal achievements. Another thing is that it is important to take into consideration economic risks when using IT market proposals. This approach was used in [11], which examines in detail the levels of production risks when using IT services and their possible reduction or complete elimination using IT outsourcing. However, from the results of the study reported in [11], it is not clear how it is possible to completely convey the risks of using IT technologies to outsourcers. After all, their consumption is possible only directly at a given enterprise; depending on the quality and professionalism of the staff who largely determine the results of production and commercial activities.

Study [12] reports the most important selection criteria for the most acceptable IT service provider and gives recommendations on how to avoid erroneous decisions when making this choice. At the same time, the author recommends concluding short-term agreements when using IT services. However, such a recommendation contradicts the basic principle of the IT market, which is based on the long-term relationship between the consumer and the provider of IT services.

Paper [13] substantiated in detail the provisions on the existence of conditions in the national economy for the development and use of information technologies, the comprehensive development of the IT market. The authors rightly consider these factors as an appropriate driving force in ensuring the component of innovative development in the economic development of the country. However, the issues of material support for the development of information technologies remained outside their attention, which can be a significant obstacle in the processes of implementation and use of modern IT services. A similar disadvantage is inherent in work [14], in which in the ranking of factors of development of IT technologies the material component is in one of the last places.

Paper [15] proposes the structure of the IT market and investigates the existing prospects and trends of development of both the world and domestic IT markets. In addition, a correct comparison of the Ukrainian market of information and communication technologies with the markets of European countries, primarily post-Soviet countries, was made.

Some researchers suggest an overly complex IT market research apparatus, which poses certain obstacles to using the research results by a wide audience of readers. For exam- 
ple, work [16] suggests methods for modeling the processes of development of the IT industry and factors of influence on the principles of the theory of fuzzy sets. In work [10], when studying IT markets, the method of the main components and multifactorial correlation analysis is used. However, given the age of statistical data and their limitations, the results of this kind of research have an insufficient level of validity of the results of the study of the level of development of all types of IT market.

Some researchers suggest an overly complex IT market research apparatus, which poses certain obstacles to using the research results achieved by a wide audience of readers. For example, work [16] proposes methods for modeling the processes of development of the IT industry and factors of influence on the principles of the theory of fuzzy sets. In work [10], when studying IT markets, the method of the main components and multifactorial correlation analysis was used. However, given the age of statistical data and their limitations, the results of this kind of research have an insufficient level of validity of the results of the study of the level of development of all types of IT markets.

It should be noted the current features in the development of the world and national market are not fully explored in the scientific literature about information technologies. Despite the significant contribution of the results of the research to the development and ensuring the growth rate of the IT market, there is an objective need to highlight and substantiate the peculiarities of development of both the international and national IT markets. These features include the assessment of the dynamics of the cost of IT services, the sectoral and territorial structure of the development of the information technology market, training for IT industries, etc. It should be noted that the significant development of the information technology industry requires new scientific advancements. Taking into consideration the latest legislative initiatives, the analysis of the existing IT services market urgently needs its detailed study, as well as devising scientific and methodological recommendations for its development and improvement.

\section{The aim and objectives of the study}

The purpose of this research is to analyze and summarize the current state and prospects of development of the European IT services market, which provides an opportunity to highlight and substantiate its advantages and disadvantages, existing development opportunities, as well as current threats to this market.

To accomplish the aim, the following tasks have been set:

- to determine the place of the information services sector in the structure of national GDP and to investigate the dynamics of economic indicators of the national IT services market and in individual countries of the world;

- to analyze the indicators of export-import relations in the IT sector as a segment of the Ukrainian information services market;

- to investigate the economic characteristics of the internal market of information services and make a forecast of their changes;

- to determine and analyze the marketing characteristics of the IT services market, first of all, the issues related to forming the demand and promotion for IT services and their pricing, in different groups of European countries (with different material capabilities);
- to conduct research and analysis of personnel support in the IT area.

\section{The study materials and methods}

The main hypothesis of this study was that based on the results of determining the current state of the IT market, economic and marketing prospects for the further development of the IT market can be developed. This would enable IT market actors in their production and commercial activities to more reasonably plan the interaction of all elements of digitalization of their business processes and expand the scope of IT offers.

The methodical basis of the research was the provisions of the methodology of scientific cognition and system analysis in applied areas of the theory of information systems, sets, applied research based on the theory of object-oriented database management systems. Techniques such as analysis, synthesis, modeling of processes studied by description, deduction, induction, comparison were also used.

These methods were employed in the formation of indicators that characterize the current state and prospects of the development of the information technology market, as well as in the development of scientific and methodological recommendations on the prospects for its development.

As a research methodology, a consistent consideration of the components of the information technology market, research, and analysis of their characteristics is proposed. This, in particular, refers to the market capacity, the volume of export-import operations, pricing in the information services market, the quantity, quality, distribution, and training system for IT specialists.

\section{Results of studying the economic and marketing} prospects of information services market development

5. 1. Studying the economic characteristics of the current state and prospects for the development of the IT market of European countries

The current conditions for the globalization of national economies create real prerequisites for the rapid development of information technologies and their wide use in the production and entrepreneurial activities of industrial enterprises. That creates fertile conditions for the active development of entrepreneurial structures for rendering IT services to everyone who wants to receive them. Information services are used in almost every area of active operations of domestic enterprises and organizations, which creates actual prerequisites for the active development of information technologies both in a separate country and in the world in general.

To assess the importance and significance of the digital technology market, we shall conduct a study of market indicators of information development and efficiency of the information field in the world and national markets of some countries, including Ukraine. Three groups of countries were selected for a comparative analysis of the economic characteristics of the global IT market with Ukraine. The first group includes two of the most developed countries in the field of IT services - India and China. The second group is countries with an average globally estimated growth rate of the IT industry - Germany and the UK. The third group is the four countries of the post-socialist camp - Poland, the Czech Republic, the Russian Federation, and Slovakia; these countries have a similar economy (Table 1). 
Table 1

Dynamics of IT market economic indicators in European countries

\begin{tabular}{|c|c|c|c|c|c|c|c|c|c|c|c|}
\hline \multirow[b]{2}{*}{ Indicator } & \multirow[b]{2}{*}{ Year } & \multirow[b]{2}{*}{ World } & \multicolumn{9}{|c|}{ Country } \\
\hline & & & $\begin{array}{c}\text { Great } \\
\text { Britain }\end{array}$ & China & India & $\begin{array}{c}\text { Germa- } \\
\text { ny }\end{array}$ & $\begin{array}{c}\text { Russian } \\
\text { Federation }\end{array}$ & Poland & $\begin{array}{c}\text { Czech } \\
\text { Republic }\end{array}$ & Slovakia & Ukraine \\
\hline \multirow{6}{*}{$\begin{array}{l}\text { IT technology } \\
\text { market capacity } \\
\text { (value estimate), } \\
\text { USD billion }\end{array}$} & 2015 & 2302 & 211 & 763 & 201 & 176 & 4.52 & 3.6 & 0.5 & 3.4 & 2.5 \\
\hline & 2016 & 2704 & 209 & 727 & 211 & 175 & 4.65 & 3.8 & 0.8 & 3.3 & 3.0 \\
\hline & 2017 & 3487 & 229 & 798 & 254 & 183 & 4.76 & 5.6 & 1.1 & 3.4 & 3.8 \\
\hline & 2018 & 3654 & 241 & 886 & 237 & 187 & 4.84 & 11 & 1.2 & 3.6 & 4.6 \\
\hline & 2019 & 3797 & 327 & 992 & 297 & 198 & 5.57 & 13 & 1.5 & 3.8 & 5.3 \\
\hline & 2020 & 3677 & 316 & 1078 & 288 & 212 & 6.75 & 19 & 1.4 & 4.1 & 7.0 \\
\hline \multirow{6}{*}{$\begin{array}{l}\text { Share of GDP of } \\
\text { the country cor- } \\
\text { responding to the } \\
\text { capacity (value) of } \\
\text { the IT technology } \\
\text { market, \% }\end{array}$} & 2015 & - & 7.2 & 6.8 & 9.5 & 5.2 & 1.1 & 0.6 & 5.2 & 4.2 & 2.8 \\
\hline & 2016 & - & 7.8 & 6.4 & 9.3 & 5.0 & 1.4 & 0.7 & 4.9 & 3.7 & 3.3 \\
\hline & 2017 & - & 7.9 & 6.6 & 9.0 & 5.2 & 1.5 & 0.9 & 5.4 & 3.9 & 3.4 \\
\hline & 2018 & - & 8.0 & 6.9 & 8.7 & 5.6 & 1.7 & 1.2 & 5.6 & 3.8 & 3.6 \\
\hline & 2019 & - & 8.2 & 7.1 & 8.0 & 6.2 & 1.8 & 1.4 & 5.4 & 3.6 & 3.8 \\
\hline & 2020 & - & 8.1 & 7.15 & 8.1 & 6.6 & 1.8 & 1.7 & 5.8 & 3.9 & 4.0 \\
\hline \multirow{6}{*}{$\begin{array}{l}\text { Share of foreign } \\
\text { trade in the } \\
\text { country (share of } \\
\text { IT technologies } \\
\text { exports in the } \\
\text { country's total } \\
\text { exports), \% }\end{array}$} & 2015 & 9.61 & 3.0 & 11.2 & 35.2 & 10.3 & 4.2 & 9.7 & 16.0 & 11.2 & 3.49 \\
\hline & 2016 & 10.2 & 3.1 & 12.1 & 35.7 & 11.5 & 5.1 & 10.5 & 14.2 & 10.8 & 4.29 \\
\hline & 2017 & 10.8 & 3.4 & 12.0 & 35.8 & 11.3 & 5.3 & 10.9 & 15.0 & 11.0 & 4.61 \\
\hline & 2018 & 11.2 & 3.8 & 12.8 & 36.1 & 11.2 & 6.4 & 11.3 & 15.4 & 11.3 & 5.41 \\
\hline & 2019 & 11.5 & 4.2 & 12.9 & 36.4 & 11.8 & 7.1 & 11.6 & 15.2 & 11.5 & 6.57 \\
\hline & 2020 & 11.3 & 4.0 & 13.1 & 35.9 & 11.6 & 7.0 & 12.2 & 15.1 & 10.9 & 8.29 \\
\hline \multirow{6}{*}{$\begin{array}{l}\text { The rate of change } \\
\text { in the capacity } \\
\text { of the country's } \\
\text { IT technology } \\
\text { market, \% }\end{array}$} & 2015 & 127.9 & 159.0 & 121 & 122 & 85.7 & 6.9 & 113 & 14.9 & 97.3 & 85.7 \\
\hline & 2016 & 117.5 & 99.2 & 95.3 & 105 & 99.3 & 6.7 & 106 & 15.3 & 97.2 & 99.5 \\
\hline & 2017 & 110.5 & 109.6 & 109.8 & 120.4 & 104.6 & 102.4 & 147 & 137 & 103 & 124 \\
\hline & 2018 & 108.9 & 105.2 & 111.0 & 93.3 & 102.2 & 101.7 & 196 & 109 & 106 & 128 \\
\hline & 2019 & 115.5 & 135.7 & 111.9 & 125.3 & 105.9 & 115.1 & 118 & 125 & 106 & 130 \\
\hline & 2020 & 97.9 & 96.6 & 108.7 & 97.0 & 107.1 & 121.2 & 146 & 93 & 108 & 120 \\
\hline
\end{tabular}

Source: compiled and systematized using [17, 18$]$

The data in Table 1 show that countries that occupy leading positions in the IT-sphere (India and China) have consistently stable dynamics of increasing the volume of their IT market. The slower growth rate of the IT services market is demonstrated by countries with the average development of the IT services sector (Great Britain and Germany). In general, the same trend is typical of post-socialist countries (Poland, Czech Republic, Russia, and Slovakia).

It should be noted that in general, the countries of the last group have a tendency to actively develop the IT industry in modern conditions, which begins to occupy leading positions both in the structure of GDP and in the export structure of the studied countries. Provided that they make certain efforts aimed at improving the infrastructure support of the IT sphere, the level of investment attractiveness for potential investors could increase significantly.

\section{2. Export-import relations in the field of informa-} tion services (external IT market)

In the post-Soviet countries, the information services market is in a state of active development and growth, which is confirmed by its leading role in the formation of export directions of various kinds of services (only the transport services sector is in the best condition) [16]. In particular, IT services show a steady increase annually, which, for example, in the Ukrainian economy, exceeds $20 \%$, ensuring its leading role in international markets [19]. In 2020, this IT market increased by almost $20 \%$, and the share of IT technologies exports in the export structure exceeded $8 \%$ [20]. In 2019-2020, more than 100 companies in the world used IT outsourcing services rendered by Ukrainian enterprises. This situation confirms a significant economic interest in the field of information services, indicates the presence of a large demand for them, and forms a significant number of real opportunities for the development and strengthening of the economic potential of each country.

National IT companies cooperate with large and small businesses around the world. More than 100 Fortune 500 companies are clients of IT firms from post-Soviet countries. As for key industries, Ukrainian IT providers specialize mainly in data management in telecommunications, clouds, games, e-commerce, media, fintech, healthcare, etc.

A special place in the European IT market belongs to Ukraine, which, despite significant problems in economic and social development, occupies a fairly decent place in the global market of IT services. The growth of IT services exports in the country over the past 6 years has more than doubled and exceeded USD 3 billion (Fig. 1).

The data in Fig. 1 demonstrate that in 2020, national IT exports exceeded USD 3 billion. This figure is approaching the volume of transport services and exceeds revenues from pipeline transport (for example, the use of a pipe for gas supplies 
from Russia to Europe) - USD 2.43 billion. It should be noted that transportation is the traditional export leader of Ukraine in the field of services (in 2020, USD 4.99 billion).

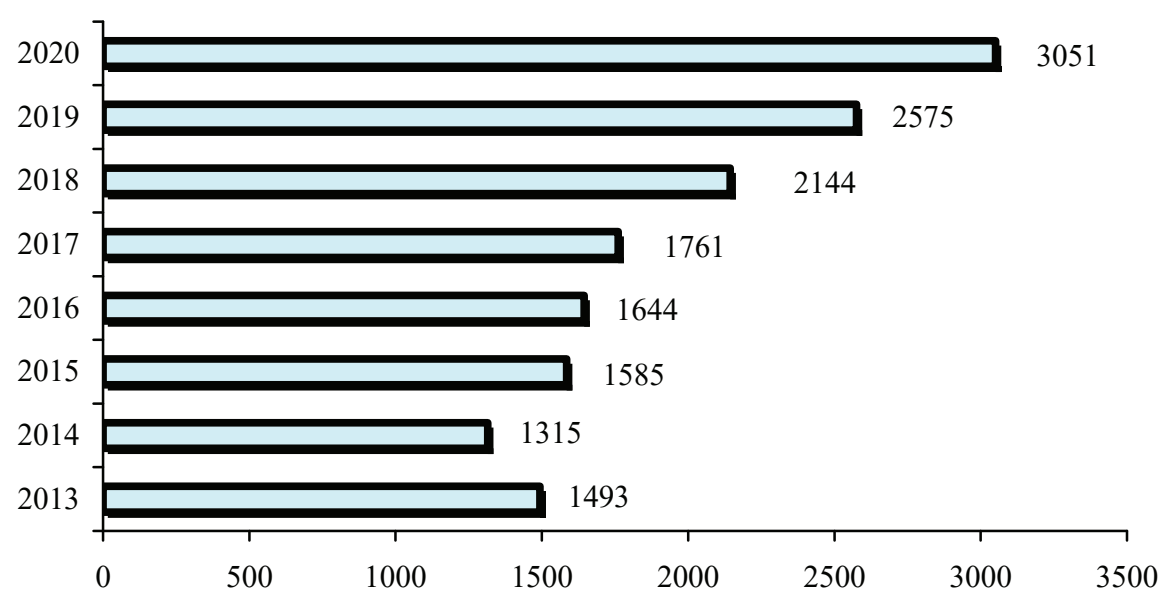

Fig. 1. Dynamics of Ukrainian IT services exports (USD million) Source: compiled using data from [21,22]

The dynamics of the export of services from Ukraine by their types are given in Table 2.Analysis of the data from Tables 1, 2 allows us to conclude that the pace of growth in information services exports is growing at a high rate. At the same time, the volume of exports of materials processing services and transport services has practically not undergone significant changes. Therefore, a significant increase in the volume of exports of information services allows the national economy to have positive dynamics of exports of services in general.

Dynamics of Ukrainian exports of
services by the most important types, USD million

\begin{tabular}{|c|c|c|c|c|c|}
\hline \multirow{3}{*}{ Year } & \multicolumn{5}{|c|}{ Service type } \\
\cline { 2 - 7 } & Total & $\begin{array}{c}\text { Infor- } \\
\text { ma- } \\
\text { tion } \\
\text { ser- } \\
\text { vices }\end{array}$ & $\begin{array}{c}\text { Trans- } \\
\text { por- } \\
\text { tation } \\
\text { ser- } \\
\text { vices }\end{array}$ & $\begin{array}{c}\text { Ma- } \\
\text { terial } \\
\text { pro- } \\
\text { cess- } \\
\text { ing }\end{array}$ & $\begin{array}{c}\text { Oth- } \\
\text { er } \\
\text { ser- } \\
\text { vices }\end{array}$ \\
\hline 2013 & 14836 & 1493 & 8305 & 1706 & 3332 \\
\hline 2014 & 11520 & 1315 & 6101 & 1675 & 2429 \\
\hline 2015 & 9737 & 1585 & 5263 & 1059 & 1830 \\
\hline 2016 & 9867 & 1644 & 5300 & 1117 & 1806 \\
\hline 2017 & 10714 & 1761 & 5861 & 1399 & 1693 \\
\hline 2018 & 11637 & 2114 & 5800 & 1692 & 2031 \\
\hline 2019 & 15629 & 2575 & 9109 & 1633 & 2312 \\
\hline 2020 & 11387 & 3051 & 4990 & 1211 & 2135 \\
\hline
\end{tabular}

Source: compiled using data from [23]

5. 3. Economic characteristics of the domestic national information services market

In addition to the export of IT technologies, much work in the post-Soviet countries is carried out on the formation of a purely national information technology market. It should be noted that in this area the situation is not as good as in the field of the external market. Such a conclusion can be confirmed, for example, by the dynamics of the capacity of the Ukrainian IT technology market (Fig. 2).

The analysis of the forecast of changes in the volume of national domestic IT technologies markets allows us to state that, in general, 2021 can be termed 2020 Light. On the one hand, there is the recovery and growth of the market, as well as the beginning of mass vaccination against the coronavirus pandemic, on the other hand, new waves of the disease, which, given the experience already available, could be a little easier. Therefore, it is impossible to even dream that the vaccination rate at about $70-80 \%$ of the population in this country could be reached by the end of 2022, according to scientists. This means that in the winter of 2021-2022 the European countries would face a new wave of diseases, which in some way can affect the state of the IT market. It is difficult to say something unequivocally but, taking into consideration the above analysis, the percentage of growth in national IT markets starting in 2021 will be to some extent less than expected two years ago.

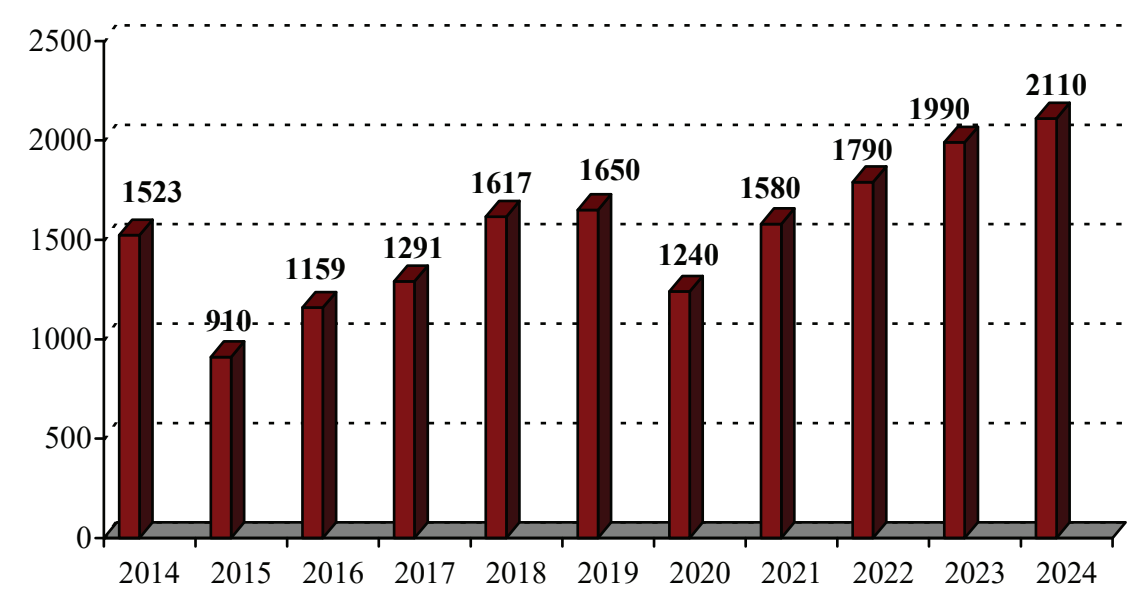

Fig. 2. Dynamics and forecast of the capacity of the Ukrainian IT services market Source: compiled using data from [21, 22]

More accurate results of the forecast of the impact of the IT market on GDP growth and the level of export operations can be obtained using economic and mathematical modeling, in particular, the tools of correlation and regression analyses. For example, paper [25] attempts to forecast IT market volumes using a trendline. The author-proposed application has generated a trendline equation that could be used to predict future values of the forecast value. The trendline equation takes the form

$$
y=1.1618 x-2321.8
$$

where $y$ is the predictive value; $x$ - years [25]. Although such forecasts are not recommended to be used in the long term due to possible changes in macro-and micro-envi- 
ronment, it may be advisable to apply them to analyze the current state of the IT market.

\section{4. Marketing characteristics of the IT services market}

The most important marketing characteristics of the IT market are demand, supply, and price. These characteristics form the market conditions and prospects for its development. Modern trends in the formation and expansion of any market are most closely related to its pricing principles. The IT services market is no exception in this sense since the price of IT services is a message that the consumer reads between the lines. Before one puts a price on a product, one needs to analyze what the seller (manufacturer, provider) of IT services wants to say. If the service is offered cheaply, then the potential buyer is given a message that $\mathrm{s} /$ he saves money. If the price is higher than the market average, the seller declares that the services are the best. It is proposed to pay in installment parts every month - this is a corresponding hint that one does not need to immediately put out a lot of money. With one-time payments - the buyer is convinced that it is more profitable than to pay forever.

Market laws of supply and demand make it possible to conclude that the more developers are represented, for example, in the software market, the better the "price-quality" ratio. This can be explained by the simple law of competition: the more competitors, the better and more adaptive the IT service developer should be to stay competitive in a given IT market.

The study of the level of prices for IT services in the post-Soviet countries has a certain landscape of its distribution in the countries of this group (Table 3 ).

Price characteristics of IT service market in post-Soviet countries

\begin{tabular}{|c|c|c|c|c|c|c|}
\hline \multirow{2}{*}{$\begin{array}{c}\text { Price } \\
\text { range, } \\
\begin{array}{c}\text { US dol- } \\
\text { lars per } \\
\text { hour }\end{array}\end{array}$} & Ukraine & Russia & Belarus & $\begin{array}{c}\text { Moldo- } \\
\text { va }\end{array}$ & $\begin{array}{c}\text { Arme- } \\
\text { nia }\end{array}$ & $\begin{array}{c}\text { Average } \\
\text { for a } \\
\text { group } \\
\text { of coun- } \\
\text { tries }\end{array}$ \\
\hline To 20 & $65.5 \%$ & $59.5 \%$ & $58.7 \%$ & $75.7 \%$ & $67.8 \%$ & $63.4 \%$ \\
\hline $21 \ldots 30$ & $24.8 \%$ & $25.9 \%$ & $29.5 \%$ & $18.4 \%$ & $25.3 \%$ & $25.2 \%$ \\
\hline $31 \ldots 40$ & $6.8 \%$ & $9.4 \%$ & $7.4 \%$ & $4.8 \%$ & $5.2 \%$ & $7.7 \%$ \\
\hline $41 \ldots 50$ & $1.6 \%$ & $2.6 \%$ & $3.4 \%$ & $0.3 \%$ & $1.1 \%$ & $1.9 \%$ \\
\hline $51 \ldots 100$ & $1.0 \%$ & $2.2 \%$ & $0.6 \%$ & $0.8 \%$ & $0.5 \%$ & $1.4 \%$ \\
\hline $\begin{array}{c}\text { Exceed- } \\
\text { ing } 100\end{array}$ & $0.4 \%$ & $0.4 \%$ & $0.4 \%$ & $0.0 \%$ & $0.0 \%$ & $0.3 \%$ \\
\hline
\end{tabular}

Source: compiled using data from [26]

The data given in Table 3 show that the most widely used price for IT services in the post-Soviet countries is up to USD 20 per hour. At the same time, the most expensive category (more than USD 100 per hour) is characteristic of only $0.3 \%$ of respondents. Here, the Russian Federation is the only country in the region with a significant number of representatives working in the range of USD 51...100 per hour $(2.2 \%)$; in all other countries surveyed, the corresponding number is less than $1 \%$. In general, the services of most freelancers and IT companies from the post-Soviet countries (more than $90 \%$ ) are priced at less than USD 30 per hour.

One of the hypotheses that explain the price level of IT services in post-Soviet countries reduces their importance to the low standard of living of citizens of these countries and their corresponding opportunities for the purchase and consumption of IT services.

To confirm or refute this opinion, we shall conduct an appropriate study of the price preferences of consumers in IT markets in other countries with higher consumer opportunities for the purchase and use of information services (Table 4).

Of all the above groups, the Baltic States is the smallest market for IT services. Only 1,162 outsourcing firms work there, for example, even compared to a group of post-Soviet countries (2,328 firms and 15,280 small private enterprises). In this sense, Ukraine is the second country after Great Britain on the European continent by the number of registered IT specialists. There are 9,272 firms and free entrepreneurs (freelancers), that is, about $16 \%$ of the European quantity.

Table 4

Price characteristics of the IT services market in different groups of European countries (with different material capabilities)

\begin{tabular}{|c|c|c|c|c|c|c|}
\hline $\begin{array}{c}\text { Price } \\
\text { range, } \\
\begin{array}{c}\text { USD } \\
\text { dollars } \\
\text { per } \\
\text { hour }\end{array}\end{array}$ & $\begin{array}{c}\text { Post-So- } \\
\text { viet } \\
\text { countries }\end{array}$ & $\begin{array}{c}\text { Baltic } \\
\text { coun- } \\
\text { tries }\end{array}$ & $\begin{array}{c}\text { Eastern } \\
\text { Europe }\end{array}$ & $\begin{array}{c}\text { Bal- } \\
\text { kan } \\
\text { coun- } \\
\text { tries }\end{array}$ & $\begin{array}{c}\text { Scandi- } \\
\text { navia }\end{array}$ & $\begin{array}{c}\text { West- } \\
\text { ern } \\
\text { Eu- } \\
\text { rope }\end{array}$ \\
\hline To 20 & $63,4 \%$ & $55,6 \%$ & $58,1 \%$ & $67,8 \%$ & 31,9 & $29,7 \%$ \\
\hline $21 \ldots 30$ & $25,2 \%$ & $22,1 \%$ & $24,5 \%$ & $19,3 \%$ & 17,5 & $19,9 \%$ \\
\hline $31 \ldots 40$ & $7,7 \%$ & $9,7 \%$ & $9,6 \%$ & $6,8 \%$ & 13,0 & $13,0 \%$ \\
\hline $41 \ldots 50$ & $1,9 \%$ & $5,8 \%$ & $3,8 \%$ & $3,2 \%$ & 10,0 & $9,2 \%$ \\
\hline $51 \ldots 100$ & $1,4 \%$ & $6,0 \%$ & $3,5 \%$ & $2,4 \%$ & 18,3 & $22,5 \%$ \\
\hline $\begin{array}{c}\text { Exceed- } \\
\text { ing } 100\end{array}$ & $0,3 \%$ & $0,8 \%$ & $0,6 \%$ & $0,5 \%$ & 9,2 & $5,6 \%$ \\
\hline
\end{tabular}

Source: compiled using data from [26]

\section{5. Studying the indicators of IT sector personnel} support

Business in the field of information technology, as an integral part of the world creative economy, largely depends on the qualifications, talent, skills, and knowledge of specialists working in the IT industry, and ultimately financial performance - on the quality, professionalism, and the number of specialists. Therefore, constant development and increased attention to the professional potential of the IT sector in each country is one of the most important issues for functionaries of national IT markets. IT specialists are the most valuable asset of the national IT market, the potential of which grows annually at a fairly high rate, as shown in Fig. 3 on the example of the IT market of Ukraine (Fig. 3).

In this regard, it should be noted that the popularity of technical and, in particular, IT specialties is growing: in 2020, it was $20 \%$ more applicants than two years ago. It should be noted that Ukraine is the undisputed leader in the training of specialists in the field of technical sciences. Every year, about 130,000 graduates receive a professional engineer diploma in 
our country (of which about 23,000 with an IT specialist diploma). For comparison, in France - 105 thousand, Germany 93 thousand, Turkey - 75 thousand, Great Britain -71 thousand, Poland - 66 thousand, Romania - 39 thousand [20].

At the same time, to better train specialists who must in the future meet the needs of the IT market with their knowledge, it is necessary to combine the efforts of both businesses and educators. On the one hand, young specialists need fundamental knowledge, and on the other hand, there is an urgent need for the applied skills necessary for business. First of all, these kinds of initiatives help the state actively develop the IT sector in the country. The government plans to bring the number of IT specialists to 450,000 by 2025 , and increase the share of IT services in the export of all services to $10 \%$ [27].

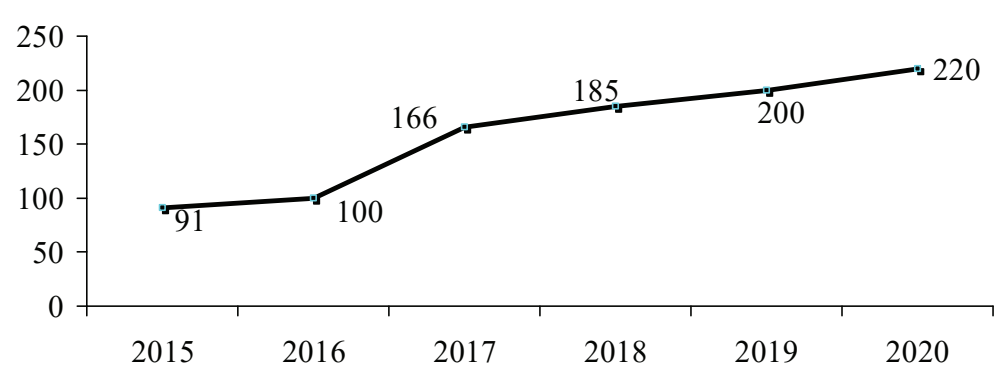

Fig. 3. Dynamics of the number of IT specialists in the economy of Ukraine (thousand people)

Source: compiled using data from [27]

According to the results of our research, specialists that attained IT education mostly work according to the skills and competencies obtained (Fig. 4). This distinguishes them favorably from specialists in other fields (for example, economists or lawyers).

It follows from the data in Fig. 4 data that the majority of IT professionals work in outsourcing companies $-46 \%$.

In the second place is the development of software products, where $29 \%$ of specialists are involved. Outstaffing (transfer and registration of an employee to a contractor company) accounts for $11 \%$. The remaining $5 \%$ of specialists work in startups and only $3 \%$ work as freelancers.

It should benoted that outsourcing workers occupy a leading place in the structure of IT sector personnel (Fig. 5). Explaining this fact, it should be noted that the domestic IT industry began active formation and development from outsourcing, which, at that time, gave the country a significant impetus in the difficult times for the domestic economy. At the beginning of the 21st century, the first IT outsourcing enterprises appeared on the European IT market: SoftServe, Miratech, ELEKS, etc. Foreign IT corporations were just beginning to discover this country at that time, so they offered only some IT functions for outsourcing, which most often did not require qualified technical expertise. It is a common practice that at one time was inherent in countries such as India, Latvia, Poland, and Romania [16].

At present, IT outsourcing enterprises make up the largest share in the national IT services country. markets. Even though the number of startups and international research centers in Europe is constantly growing, outsourcing IT companies employ most of all IT professionals living in the

A slightly different situation is observed when analyzing the experience of IT professionals in their professional field (Fig. 5).

From the above data (Fig. 5), it follows that the IT market is dominated by specialists with $3-5$ years of experience. According to the results of our survey, such employees account for more than $29 \%$. In the second place are employees with work experience of 1-2 years: $27 \%$. Closing the top three are those IT professionals who have worked for $6-10$ years: $17 \%$.

The low percentage of IT professionals with extensive experience (more than 10 years - only $14 \%$ ) is explained by the fact that the development of information technologies and, accordingly, the IT market has been actively carried out only in the last 10 years. Therefore, the training of specialists for the IT sector has been actively developed only in recent years, so the time of their work in the relevant positions is still far from high in terms of work experience. These findings are to some extent confirmed by the age distribution of IT professionals, in which the majority (more than $70 \%$ ) is occupied by a younger generation of employees under the age of 30 (Fig. 6).

It is also interesting to note such a fact from the analysis of IT specialists: most employees are men, who make up $77 \%$ of the contingent of employees at national IT enterprises [27].



Fig. 4. Distribution of specialists with IT education by place of work Source: compiled using data from [27]

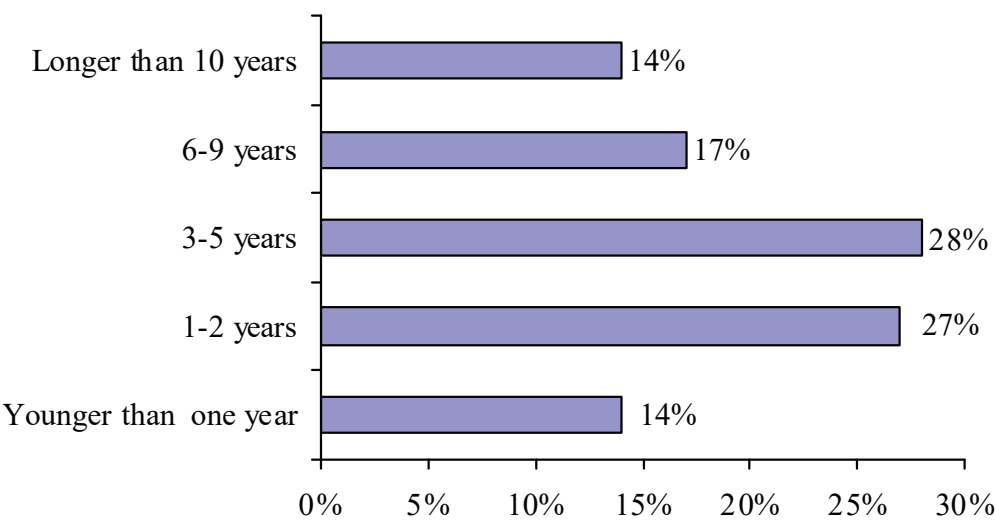

Fig. 5. Distribution of specialists with IT education by the experience of work Source: compiled using data from [27] 
As for the geography of placement and concentration of IT specialists on the territory of European countries, it should be determined that such a distribution, as a rule, is uneven. For example, in Ukraine, the largest centers of residence and work of IT specialists are Kyiv, Kharkiv, and Lviv (Fig. 7).

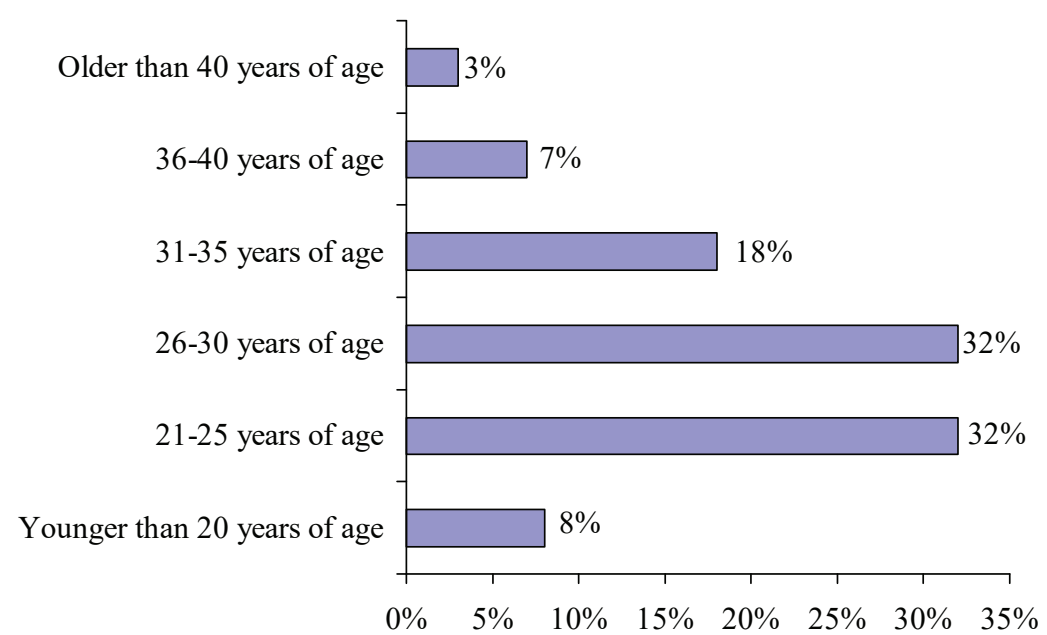

Fig. 6. Distribution of specialists in IT departments by age Source: compiled using data from [27]

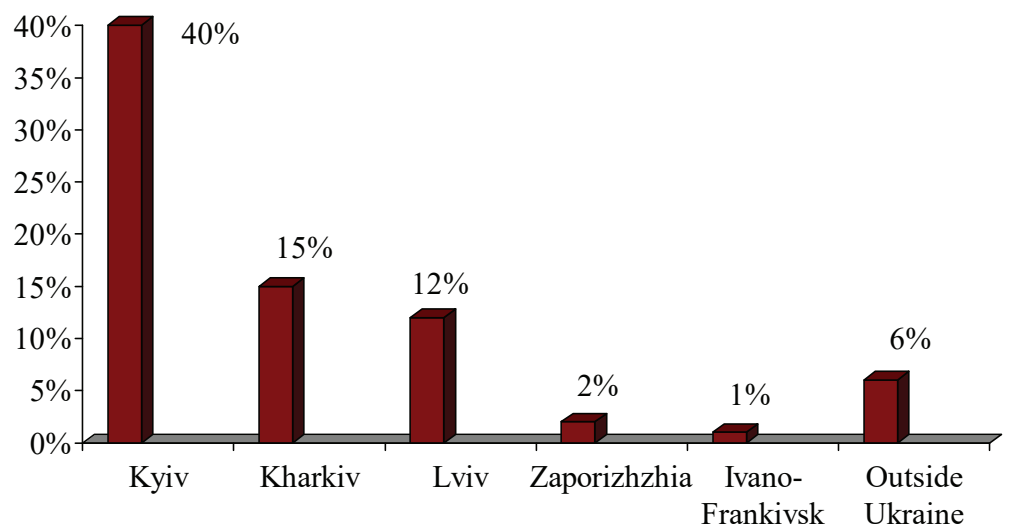

Fig. 7. Distribution of specialists in IT departments of Ukraine by age Source: compiled using data from [20]

The data in Fig. 7 allow us to assert that not all regions of Ukraine are active participants in the IT market. The minimum presence in the domestic IT market of representatives of Cherkasy, Khmelnytskyi, Mykolaiv, Kherson, etc., where there are all grounds and needs for the development of this area of business activity, looks strange.

It is not very different from the general distribution of IT specialists and their distribution in certain areas of activity. For example, software developers in their vast majority are in Kyiv (68\%), Kharkiv (23\%), Lviv (20\%), Dnipro (12\%), and Odesa (9\%) [20]. It is positive that in this distribution there are already representatives of Odesa who were absent in the previous distribution.

\section{Discussion of results of studying the impact of outsourcing on the performance of an enterprise}

The results of our research show that the dynamics of IT market development in some European countries demonstrate a steady trend of active development of the IT industry. This trend begins to occupy leading positions in both the structure of GDP (Table 1) and in the structure of exports of countries (Fig. 1, Table 2). These countries have significant reserves of low-cost but highly skilled labor, as well as a far from the fully mastered capacity of the IT services market. Such countries, according to the results of our study, include Ukraine.

The research by some large investment companies (for example, AVentures Capital, Aventis Capital, Capital Times, Intellias, etc.) examines in detail the IT cluster, which was created by Ukraine, Belarus, Poland, and Romania. The total IT export volume of the four countries reached USD 13 billion. In general, they account for $5 \%$ of the world market. India and China are the leaders, covering together $80 \%$ of the information market [22].

IT service providers make up the largest share in the national information market. For example, more than $60 \%$ of local IT professionals currently work in Ukraine. And this is even though the number of startups (more than 2000 companies) and international research centers (more than 100 companies) at Ukrainian IT outsourcing enterprises is constantly increasing.

It should be noted that the United States and Western European countries remain the largest target markets for IT services enterprises from post-Soviet countries. In 2011-2012, U.S. enterprises were the largest consumers of IT services (up to $90 \%$ ) from European post-Soviet countries. Currently, the United States is still the most significant consumer of IT exports ( $81 \%$ ) but the share of European consumers over the past 10 years has increased significantly (Fig. 8).

The domestic IT market has less stable indicators of its development but the existing trends are significant enough.

Prospects for its development for the period up to 2024 predict its increase by one and a half times.

An important characteristic of the IT services market is its pricing principles. Moreover, it is extremely interesting to compare the prices of the national IT services market with prices in the markets of other countries that are located in different regions of the world.

The Baltic states, in fact, could be included in the post-Soviet region but their proximity to Western Europe and economic distance from the CIS countries played a role in the distribution of prices for IT services. On average, in the Baltic states, the cost of outsourcing development services is higher than in post-Soviet countries. Almost $1 \%$ of respondents estimate their work at more than USD 100 per hour, and as much as $6 \%$ (and in Estonia even $15 \%$ ) are in the price range of USD 51...100 per hour. At the same time, a little more than half of the representatives of the Baltic States (55\%) require a relatively low price per hour of their work in less than USD 20, which is typical of the countries of the post-Soviet group.

If we analyze the average price for IT services ( $\mathrm{Ta}-$ ble 4), then Eastern Europe is between the post-Soviet 
and Baltic countries (Tables 3, 4). However, within this region, there are significant differences in the structure of price distribution of different countries. In Poland, for example, only $40 \%$ of IT specialists have a price tag for their services of less than USD 20 per hour, and in Romania, the corresponding prices characterize $67 \%$ of respondents. Such a situation can be explained by the above-mentioned competition law: Romania ranks 4th in Europe in terms of the number of registered firms and freelancers after the UK, Ukraine, and Russia. This creates an extremely competitive environment for this country compared to the neighboring countries of the region. It should also be noted that in the lowest price interval (up to $20 \%$ ), despite the rather high standard of living, the leaders are Balkan countries (67.8\%) (Table 4). At the same time, Greece, Slovenia, and Croatia differ significantly from Bosnia, Serbia, Macedonia, and Albania in the structure of price distribution for IT services. The first are more similar in this indicator to the Baltic states and Eastern Europe, while others, along with Moldova and Armenia, are European countries with the cheapest market of IT services. Please note that Serbia (population about 7 million) with 3,300 IT service providers ranks 5 th in Europe in terms of the IT services market. Most likely, this is the highest ratio of IT specialists per capita among European countries.

Scandinavian countries also have a small market of IT services (the second in the volume after the Baltics) but also the most expensive in relation to consulting and IT outsourcing services. According to the data in Table 4, less than a third of Scandinavia's IT service providers ask less than USD 20 per hour for their services, and about $10 \%$ - more than USD 100 per hour. The second most common price category among IT service developers is USD $51 \ldots 100$ per hour - almost $20 \%$ of all IT specialists is represented in the Scandinavian region.

The number of IT service providers in Western Europe, whose services are estimated at an interval of up to USD 20 per hour, is even less than in Scandinavia. At the same time, in northern countries, there are almost twice as many IT specialists who evaluate their services more than USD 100 per hour than in other European countries. The exception is

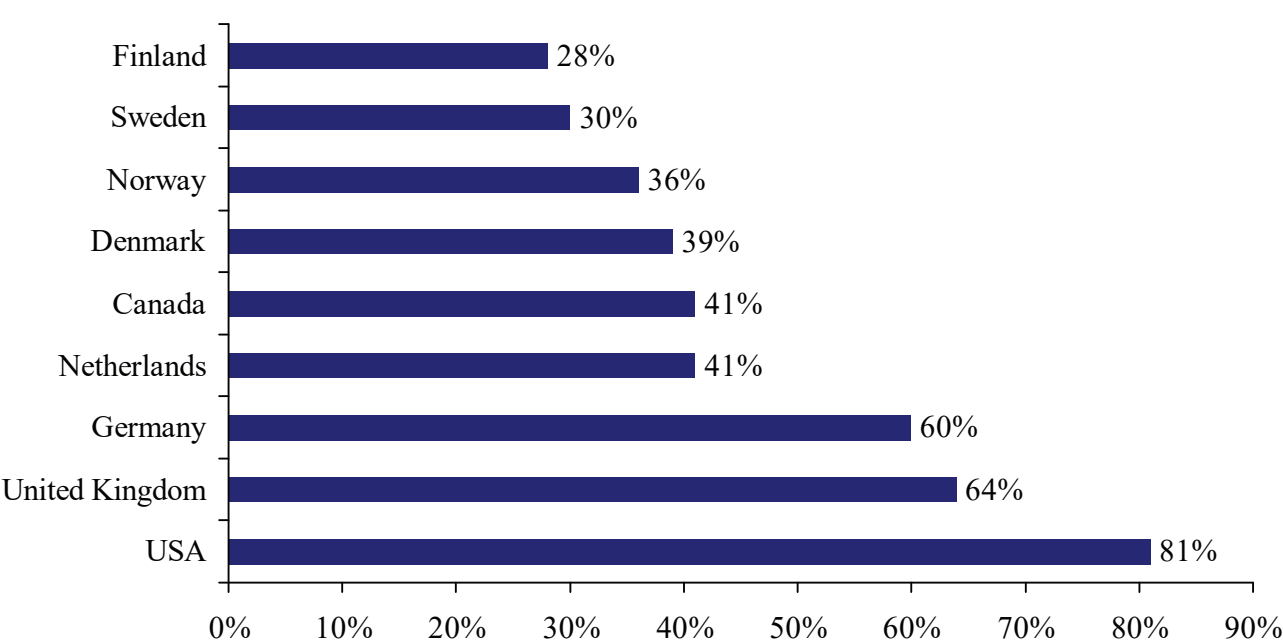

Fig. 8. Share of enterprises from the post-Soviet countries in Europe cooperating in the field of IT services with relevant enterprises of other countries Source: compiled using data from [20]
Switzerland, where the cheapest category of IT services (less than USD 20 per hour) is only $16 \%$; it is not the most common in the country. The peculiarity is inherent in Belgium, which is the only country where the second most popular price category (USD 51...100 per hour) is represented by $28 \%$ of IT service providers in the country. This fact represents Belgium as the country with the highest prices in the European IT services market in terms of the weighted average price of IT services.

The effectiveness of each market is determined by specialists working in the relevant field of activity. The generalization of the results of our survey makes it possible to state that the market demand for IT services has recently had record figures that exceed the available offers of services in the IT market. Only during 2020, the demand in the world IT services market increased by $11 \%$. This situation involves a significant increase in the need for highly qualified IT specialists. According to available research [27], more than 24.5 million specialists are already working in the IT field in the world, which is 500 thousand more than in 2020. Despite this number of specialists, the IT sector feels a significant lack of skilled labor. According to the international consulting company Korn Ferry (Los Angeles, USA), by 2030, the shortage of specialists in key areas in the world could reach 85.2 million, of which more than 4 million - in theIT industry [27].

A similar situation is observed, in particular, in Ukraine. Even though the number of IT specialists in the country is constantly growing (by about $20 \%$ for each year), the need for qualified IT personnel is increasing at a higher rate annually by $30 \%$. According to statistics provided by the IT job search platform, the number of vacancies existing on the platform for the first time in 2021 exceeds the number of potential applicants. For example, in 2020, the number of IT professionals in the country increased by $16 \%$ over the past year, and in 2021 exceeded 215 thousand. However, even in the presence of such indicators, from the fall of 2020, the IT sector of the Ukrainian IT technology market recorded a rapid increase in demand for IT specialists. At the end of 2020, according to the job search platform, 16,000 positions were opened, then, in mid-2021, this figure has already exceeded 25,000 IT vacancies. In general, over the past five years, the number of job offers in the IT sector has increased by $30 \%$, and the offer of IT specialists by only $18 \%$.

The discussion of the study results on the impact of outsourcing on the performance of an enterprise allows us to argue about the following. In the IT industry of European post-Soviet countries, there is an acute lack of qualified specialists, at a time when the complexity and importance of scientific and technical IT developments is growing at a high rate. 
Therefore, it is very important for IT professionals to improve their skills and competencies in order to be in demand in the IT market, and it is very important for IT enterprises to provide them with the necessary assistance. After all, qualified IT specialists have every opportunity to solve complex problems and perform them more effectively. According to the research reported in [27], IT enterprises, in order to be competitive and continue their rapid development, must invest at least $1.5 \%$ of their income in the educational programs of future IT professionals. The results of our study could be more thorough if there would be international market structures in the field of information technology and with a decrease in the impact of existing problems in the development of the IT market. A positive aspect of the research is the use, to substantiate proposals for the development of the IT market, of mathematical modeling of the level of its impact on the indicators of the development of Karina in general. The priority is to improve the unfavorable macroeconomic situation in the countries of the post-Soviet space, which is mainly expressed in reducing the level of purchasing power of demand for IT services. There is an urgent need to digitalize enterprises throughout the country, and not just those that are located in large cities. All this is associated with the development of a wider network of market offers of IT services, reaching out to small settlements, which, in turn, would really affect the reduction of the payback period of IT projects.

\section{Conclusions}

1. We have investigated the economic and marketing indicators of the IT market in the European post-Soviet countries. It is determined that countries that occupy leading positions in the field of information technology demonstrate stable dynamics of increasing the volume of their IT markets. Less rapid growth rates of economic indicators of the IT services market are demonstrated by those countries, including Ukraine, whose IT services sector is developed less on average.

2. The economic characteristics of the external market of IT services have been considered, in the formation of which export deliveries have a leading role. It is determined that the capacity of the international segment of the IT ser vices market in the post-Soviet countries increases by an average of $20 \%$ annually, and the share of IT technologies exports in the export structure exceeded $8 \%$.

3. Our marketing analysis of the forecast of changes in the internal market of IT technologies in the post-Soviet countries suggests that in the future the domestic IT market will grow and in 2024 could reach USD 2 billion.

4. Studying the level of prices for IT services in the post-Soviet countries suggests that they mainly correspond to the prices for similar services in different groups of European countries (with different material capabilities). This means that for consumers of IT services in these countries, price characteristics are not an obstacle to obtaining, in their opinion, the highest quality services from domestic or foreign suppliers.

5. The role and importance of personnel support of the information industry, which is the basis in the formation and development of the IT services market, have been determined. It is proven that specialists who attained IT education mostly work according to the skills and competencies obtained, which distinguishes them favorably from specialists in other sectors. Despite the tendencies of a certain outflow of specialists outside the national borders of countries, the number of IT specialists in their economy is growing progressively. In many ways, these trends are facilitated by an increase in the number of graduates from specialized educational institutions.

\section{References}

1. IT Services Outsourcing Market Size, Share \& Trends Analysis Report By Service (Application, Emerging Technology), By Location (On-shore, Off-shore), By End-use, And Segment Forecasts, 2020 - 2027. Available at: https://www.grandviewresearch.com/ industry-analysis/it-services-outsourcing-market

2. Kosenko, O., Cherepanova, V., Dolyna, I., Matrosova, V., Kolotiuk, O. (2019). Evaluation of innovative technology market potential on the basis of technology audit. Innovative Marketing, 15 (2), 30-41. doi: https://doi.org/10.21511/im.15(2).2019.03

3. Maslak, O. I., Ishchenko, S. V., Grishko, N. Y., Maslak, M. V. (2019). Export-Oriented Enterprise Development of the Electrotechnical Industry: Strategic Guidelines. 2019 IEEE International Conference on Modern Electrical and Energy Systems (MEES). doi: https:// doi.org/10.1109/mees.2019.8896494

4. Illiashenko, S., Rot-Sierov, Y. (2016). Knowledge as a factor of competitive advantages: prospects for Ukraine. Economic AnnalsXXI, 156 (1-2), 49-53. doi: https://doi.org/10.21003/ea.v156-0011

5. Pererva, P., Kuchynskyi, V., Kobielieva, T., Kosenko, A., Maslak, O. (2021). Economic substantiation of outsourcing the information technologies and logistic services in the intellectual and innovative activities of an enterprise. Eastern-European Journal of Enterprise Technologies, 4 (13 (112)), 6-14. doi: https://doi.org/10.15587/1729-4061.2021.239164

6. Top IT outsourcing destinations of Eastern Europe: Market report. Available at: https://www.n-ix.com/it-outsourcing-destinationseastern-europe-market-report/

7. Pererva, P., Besprozvannykh, O., Tiutlikova, V., Kovalova, V., Kudina, O., Dorokhov, O. (2019). Improvement of the Method for Selecting Innovation Projects on the Platform of Innovative Supermarket. TEM Journal, 8 (2), 454-461. doi: https://doi.org/10.18421/TEM82-19

8. The 2021 Global Outsourcing 100. Available at: https://www.iaop.org/Content/19/165/5309

9. Pererva, P., Kobielieva, T., Tkachova, N., Tkachov, M., Diachenko, T. (2021). Management of relations with enterprise stakeholders based on value approach. Problems and Perspectives in Management, 19 (1), 24-38. doi: https://doi.org/10.21511/ppm.19(1).2021.03

10. Pererva, P., Hutsan, O., Kobieliev, V., Kosenko, A., Kuchynskyi, V. (2018). Evaluating elasticity of costs for employee motivation at the industrial enterprises. Problems and Perspectives in Management, 16 (1), 124-132. doi: https://doi.org/10.21511/ ppm.16(1).2018.12 
11. Maslak, O., Grishko, N., Vorobiova, K., Hlazunova, O., Maslak, M. (2017). Developing the intra-firm technology transfer system at the industrial enterprise based on matrix approach. Problems and Perspectives in Management, 15 (3), $242-252$. doi: https://doi.org/10.21511/ppm.15(3-1).2017.08

12. Maslak, O. I., Grishko, N. Ye., Hlazunova, O. O., Vorobiova, K. O. (2017). Approaches to the management of the costs of innovation activity of mining enterprises: Aspects of economic security. Naukovyi Visnyk Natsionalnoho Hirnychoho Universytetu, 5, 137-145. Available at: http://nbuv.gov.ua/UJRN/Nvngu_2017_5_22

13. Pererva, P., Usov, M., Chernobrovkina, S., Larka, L., Rudyka, V. (2021). Methods for Assessing the Investment Attractiveness of Innovative Projects. Studies of Applied Economics, 39 (6). doi: https://doi.org/10.25115/eea.v39i6.5167

14. Pererva, P., Kobielieva, T., Kuchinskyi, V., Garmash, S., Danko, T. (2021). Ensuring the Sustainable Development of an Industrial Enterprise on the Principle of Compliance-Safety. Studies of Applied Economics, 39 (5). doi: https://doi.org/10.25115/eea.v39i5.5111

15. Novikova, A., Skorobogatova, N. (2018). Analysis of the world and Ukrainian IT services market development. Investytsiyi: praktyka ta dosvid, 3, 52-56. Available at: http://www.investplan.com.ua/?op=1\&z=5914\&i=9

16. Ovcharenko, D. (2020). IT v Ukraini: kudy my rukhaiemosia. DOU. Available at: https://dou.ua/lenta/columns/future-of-it-ukraine/

17. KNOEMA. Available at: https://knoema.ru/

18. Integrated foreign economic information porta. Available at: http://www.ved.gov.ru/exportcountries/

19. Indeks razvitiya informacionno-kommunikacionnyh tehnologiy. Available at: https://gtmarket.ru/ratings/ict-development-index

20. The country that codes. IT Industry in Ukraine. 2019 Market Report. Available at: https://s3-eu-west-1.amazonaws.com/new.n-ix.com/ uploads/2019/09/26/Software_development_in_Ukraine_2019_2020_IT_industry_market_report.pdf

21. IT-Експорт у 2020. Available at: https://brdo.com.ua/wp-content/uploads/2021/02/IT-eksport-u-2020-2.pdf

22. IT-eksport Ukrainy dostig $\$ 4,5 \mathrm{mlrd}$. V strane 245 kompaniy s bolee chem 50 sotrudnikami - otchet. Available at: https:// vctr.media/software-development-cee-report-15383/

23. State Statistics Service of Ukraine. Available at: https://ukrstat.org/

24. Prognoz ob'ema IT-rynka Ukrainy na 2020-2024 gody. Available at: https://ko.com.ua/prognoz_obema_it-rynka_ukrainy_ na_2020-2024_gody_135892

25. Meshko, N. P., Kostiuchenko, M. K. (2015). Perspektyvy rozvytku sfery IT yak providnoi innovatsiynoi haluzi Ukrainy. Visnyk Dnipropetrovskoho universytetu. Seriya «Menedzhment innovatsiy», 4, 71-77. Available at: https://www.dnu.dp.ua/docs/visnik/ fmecon/program_5e4ba43063ed9.pdf

26. Pronskiy, V. (2015). Stoimost' IT-uslug v Evrope. Rynochnoe issledovanie na baze Elance. Payoneer blog. Available at: https://blog. payoneer.com/ru/freelancers-ru-1/it-programming-ru/pricing-for-it-services-in-europe/

27. Yavorskiy, A. (2021). IT-otrasl' 2021: chto proishodit v Ukraine i mire. Interfaks-Ukraina. Available at: https://interfax.com.ua/ news/blog/755658.html 